\title{
Occurrence of Syncytes: A Possible Mechanism Owing to the Origin of Polyploid Cytotypes in Achillea millefolium L. within Indian Himalayas
}

\author{
Maninder Kaur*, Himshikha and Vijay Kumar Singhal \\ Department of Botany, Punjabi University, Patiala-147002, Punjab, India \\ Received October 20, 2016; accepted June 23, 2017
}

\begin{abstract}
Summary Present study records the existence of tetraploid and hexaploid meiocytes and subsequently the formation of large and very large-sized pollen grains for the first time in the diploid individuals of Achillea millefolium. In majority of the diploid accessions, meiocytes exhibited nine bivalents, equal segregation of chromosomes during anaphases, regular tetrads and normal-sized ' $n$ ' pollen grain formation. In the accessions scored from Palchan $(2400 \mathrm{~m})$ and Dhundhi $(3050 \mathrm{~m})$ regions of Solang Valley, two to three proximate PMCs fused during early stages of Prophase-1 and Metaphase-1 resulting into tetraploid (4x) and hexaploid (6x) meiocytes with 18 and 27 bivalents, respectively. Although the frequency of polyploid PMCs was rather low these are detectable due to their larger size compared to diploid PMCs. In both the accessions, the diploid and polyploid PMCs exhibited the multiple chromosomal associations of four to eight chromosomes indicating the existence of structural heterozygosity. Analysis reveals that there is an increase in the chiasma frequency with structural heterozygosity for reciprocal translocations. Syncyte meiocytes followed a regular meiotic course resulting into the formation of normal tetrads but the products of such sporads yielded atypical (large and very large-sized) pollen grains compared to normal sized typical pollen grains. Although the exact cytological status of aforesaid pollen grains could not be ascertained but such fertile larger-sized pollen grains with possible ' $2 n$ ' or ' $3 n$ ' genetic constitution might be involved in fertilization to generate polyploid offsprings and the origin of intraspecific polyploid cytotypes $(4 x, 6 x)$ which are known to exist in some populations of Himalayas in India.
\end{abstract}

Key words Meiosis, Syncytes, Quadrivalents, Tetraploid, Hexaploid, Pollen grains.

Achillea millefolium which is a highly polymorphic and widely distributed species in India and other parts of the world is one of the best studied species with regard to chromosome counts. Probably, the earliest chromosome counts from Europe and other parts of the world were those of Clausen et al. (1941), Löve and Löve (1944, 1948), Felföldy (1947), Polya (1948, 1949, 1950), and Harling (1950). Gervais (1977) who made an extensive cytological investigations from Quebec, Canada reported tetraploid $(2 n=36)$, pentaploid $(2 n=45)$, hexaploid $(2 n=54)$ and some aneuploid cytotypes and suggested it to be a species complex. Rehberger (2000) reported an octoploid $(2 n=72)$ cytotype along with tetraploid and hexaploid cytotypes from Austria, Central Europe. Chromosome numbers of Achillea millefolium complexes have been put into six categories ranges from diploid to octoploid (Danihelka and Rotreklová 2001). In Indian Himalayas also, the species is known to exist at different ploidy levels, ranging from diploid, $2 n=18$ (Shetty 1964, Mehra et al. 1965, Mehra and Remanandan 1974, Kaur and Singhal 2015, Rana et al. 2015); tetraploid, $2 n=36$ (Mehra and Remanandan 1974); and hexaploid, $2 n=54$

* Corresponding author, e-mail: maninderdhot84@gmail.com DOI: $10.1508 /$ cytologia.82.375
(Mehra and Remanandan 1974). A cursory look at the chromosomal data on the species reveals that worldwide it shows a considerable amount of heterogeneity $(2 n=18,27,35,36,44,45,53,54,63,72,74,81 \pm 5)$ involving both aneuploidy and polyploidy. Ehrendorfer $(1953,1959)$ suggested that $A$. millefolium is a polyploid complex consisting of six taxa; two at diploid level ( $A$. asplenifolia and $A$. setacea), one at diploid and tetraploid level (A. roseoalba), one at the tetraploid level only $(A$. collina), another one a hexaploid (A. millefolium) and sixth being an octoploid (A. pannonica). Spontaneous hybridization across different ploidy levels is also existent which is evident from the existence of triploid $(2 n=27)$, pentaploid $(2 n=45)$ and heptaploid $(2 n=63)$ plants as reported by workers in the different parts of the world (Danihelka and Rotreklová 2001). Ehrendorfer (1957, 1960a, 1960b) opined that evolution in the species seems to be more complex involving some other cytological processes rather than the ploidy level alone. Accessory or B-chromosomes have also been reported in the species in tetraploid $(2 n=36)$ and hexaploid $(2 n=56)$ cytotypes (Ehrendorfer 1960a, Lavrenko and Serditov 1991, Androshchuk et al. 1979, Saukel and Langer 1992, Danihelka and Rotreklová 2001). Another phenomenon which has played an important role in the evolution of 
the species is the existence of structural heterozygosity for reciprocal translocations in diploid individuals of N-W Himalayas (Singhal et al. 2014). Such chromosomal interchanges are likely to increase the amount of genetic variability in the gametes forming new genetic linkage groups which may be used for adaptation to adverse climatic conditions. Though the species has been worked out cytologically quite extensively from Indian Himalayas by workers from this laboratory (Malik 2012, Bala and Gupta 2011, Singhal et al. 2014, Kaur and Singhal 2015, Rana et al. 2015), majority of the populations exist at diploid level with $2 n=18$. However, a comprehensive study of this species complex is still lacking from some of the geographically isolated and unexplored regions of N-W Himalayas in India. The purpose of the present study was (1) to critically evaluate the chromosome counts on individual plant basis, (2) to locate the structural hybrids, and (3) to study any other cytological evolutionary process involved in the origin of intraspecific polyploid cytoypes.

\section{Materials and methods}

Materials for cytological studies were collected from the wild plants growing at various altitudinal ranges of Solang valley and Parvati valley of Kullu District, Himachal Pradesh during the months of April-September, 2010-2013 from different localities. Voucher specimens of the cytological worked out accessions were deposited in the Herbarium, Department of Botany, Punjabi University, Patiala. For male meiotic studies, capitula of suitable sizes were fixed in Carnoy's fixative (mixture of ethanol, chloroform and glacial acetic acid in a volume ratio of $6: 3: 1$ ) for $24 \mathrm{~h}$, transferred to $70 \%$ alcohol and stored in a refrigerator until analysis. Pollen mother cells (PMCs) were prepared by squash technique and stained with $1 \%$ acetocarmine. Freshly prepared slides were carefully examined to determine the chromosome number. PMCs were also analyzed for detailed meiotic behavior at different meiotic stages, diakinesis, metaphase I (MI), anaphase-I/II (AI/II), telophase-I/II (TI/II) and sporad stage. In accessions with normal meiotic course, a total of 100-150 PMCs were examined for determining the chromosome counts, while in case of accessions showing larger-sized PMCs, a total of 1678 PMCs prepared from different anthers/florets were analyzed. Pollen fertility was estimated through stainability tests by squashing the anthers from mature capitula in

Table 1. Province, locality, altitudes, accession number, meiotic chromosome number ( $n$ ), meiotic course, and pollen fertility \% in Achillea millefolium. ST=Structural heterozygote.

\begin{tabular}{|c|c|c|c|c|c|c|c|c|c|c|}
\hline \multirow[b]{2}{*}{$\begin{array}{c}\text { Province, locality, } \\
\text { altitudes }\end{array}$} & \multirow{2}{*}{$\begin{array}{l}\text { Acces- } \\
\text { sion } \\
\text { number } \\
\text { (PUN) }\end{array}$} & \multirow{2}{*}{$\begin{array}{l}\text { Chromo- } \\
\text { some } \\
\text { number } \\
(n)\end{array}$} & \multirow[b]{2}{*}{$\begin{array}{l}\text { Meiotic } \\
\text { course }\end{array}$} & \multicolumn{2}{|c|}{ No. of PMCs analysed at M-1 } & \multirow{2}{*}{$\begin{array}{c}\% \text { of } \\
\text { PMCs } \\
\text { with lag- } \\
\text { gards at } \\
\text { A-1 }\end{array}$} & \multirow{2}{*}{\multicolumn{2}{|c|}{ 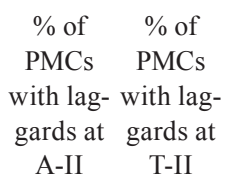 }} & \multirow[b]{2}{*}{$\begin{array}{c}\text { Pollen } \\
\text { fertility } \\
(\%)\end{array}$} & \multirow[b]{2}{*}{ Pollen grains size $(\mu \mathrm{m})$} \\
\hline & & & & $\begin{array}{l}\text { (without } \\
\text { multivalents) }\end{array}$ & $\begin{array}{c}\text { (with } \\
\text { multivalents) }\end{array}$ & & & & & \\
\hline
\end{tabular}

Kullu district

Solang Valley

$\begin{array}{lllll}\text { Palchan, } 2450 \mathrm{~m} & 58571 & 9 & \text { ST } & 42\end{array}$

$\begin{array}{lcccc}\begin{array}{l}\text { Solang Nullah, } \\ 2700 \mathrm{~m}\end{array} & 56570 & 9 & \text { Normal } & 78 \\ \begin{array}{l}\text { Solang Village, } \\ 2750 \mathrm{~m}\end{array} & 56885 & 9 & \text { Normal } & 69 \\ \begin{array}{l}\text { Dhundhi, } 3050 \mathrm{~m} \\ \text { Dhe }\end{array} & & \text { ST } & 54\end{array}$

Parvati Valley

$\begin{array}{lcclc}\text { Shaarni, 2300m } & 56092 & 9 & \text { Normal } & 93 \\ \text { Pulga, 2300m } & 56119 & 9 & \text { Normal } & 78 \\ \text { Braagha, 2600m } & 56111 & 9 & \text { Normal } & 62 \\ \text { Nareng, 2700m } & 56119 & 9 & \text { Normal } & 47 \\ \text { Mallana, 2650m } & 57165 & 9 & \text { Normal } & 102\end{array}$

19

$\begin{array}{llll}5.45 & 6.66 \quad 68.00\end{array}$

68.00

Typical sized:

$23.09 \times 21.63 \mu \mathrm{m}$

Large sized:

$25.70 \times 24.77 \mu \mathrm{m}$

Very large sized:

$31.19 \times 27.31 \mu \mathrm{m}$

Typical sized:

$21.55 \times 22.02 \mu \mathrm{m}$

Typical sized:

$22.67 \times 21.15 \mu \mathrm{m}$

Typical sized:

$20.32 \times 22.39 \mu \mathrm{m}$

Large sized:

$25.49 \times 23.37 \mu \mathrm{m}$

Very large sized:

$28.65 \times 29.32 \mu \mathrm{m}$

Typical sized:

$22.61 \times 18.98 \mu \mathrm{m}$

Typical sized:

$22.41 \times 20.49 \mu \mathrm{m}$

Typical sized:

$21.63 \times 21.10 \mu \mathrm{m}$

Typical sized:

$22.11 \times 21.00 \mu \mathrm{m}$

Typical sized:

$20.43 \times 18.88 \mu \mathrm{m}$ 


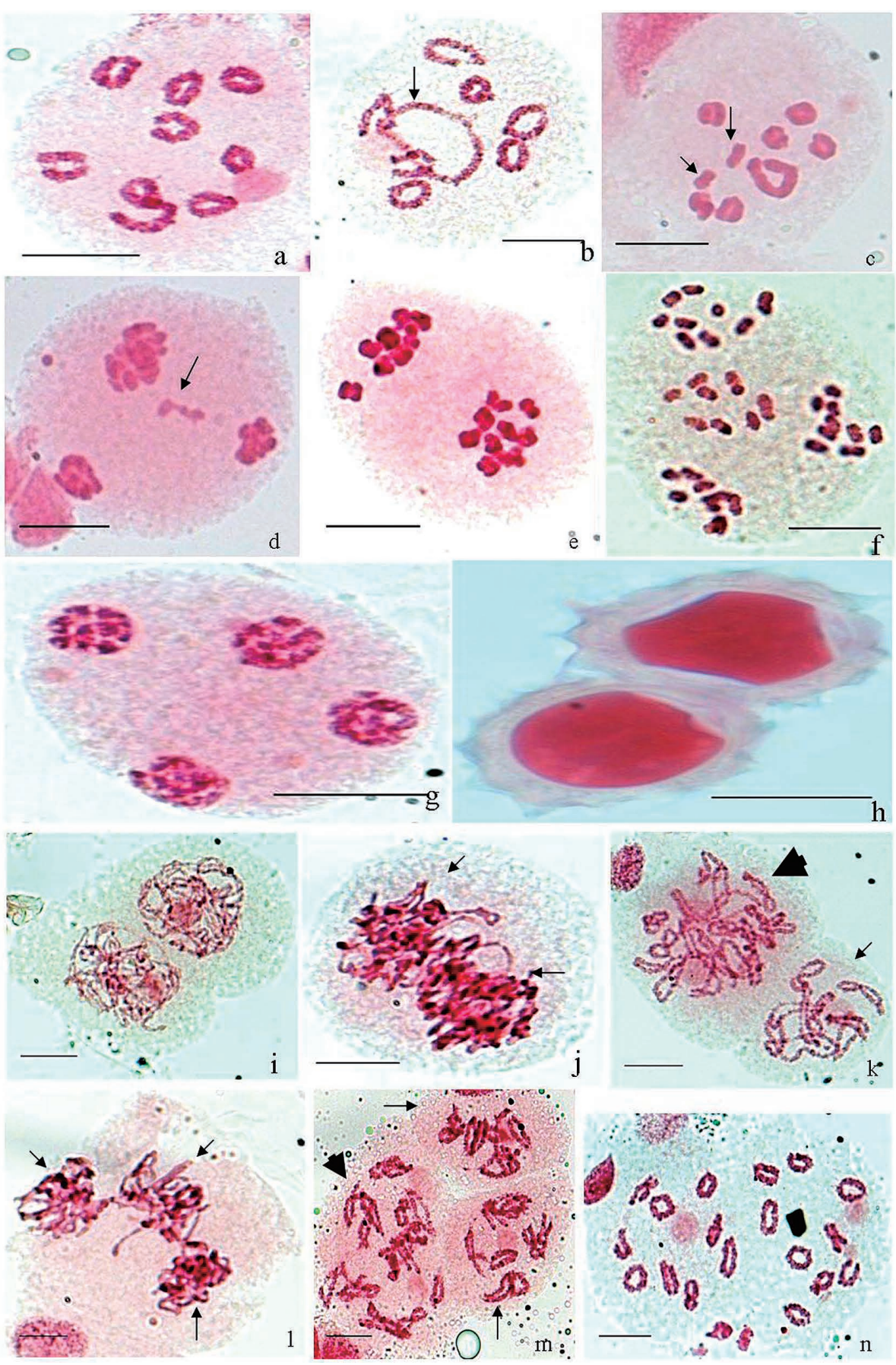

Fig. 1. (a) A PMC with nine equal sized bivalents at diakinesis. (b) A diploid PMC shows seven bivalents and one quadrivalent (arrowed). (c) A PMC with 6 bivalents, 1 quadrivalent (arrowhead), and 2 univalent chromosomes (arrowed) at M-1. (d) A PMC with a laggard at A-II (arrowed). (e) A PMC with 9:9 equal chromosomal distribution at A-I. (f) A normal diploid PMC exhibits 9:9:9:9 distribution pattern of chromosomes at A-II. (g) A PMC depicts four nuclei at T-II. (h) Identical sized typical pollen grains. (i) Two proximate PMCs undergo fusion prior to syncyte formation. (j) A large sized PMC with two chromatin mass (arrowed). (k) A large sized syncyte PMC showing double chromosome number (arrowhead) and a normal sized $2 n$ PMC (arrowed). (1) A large sized syncyte PMC with three distinct chromatin masses (arrowed). (m) A large sized tetraploid PMC (arrowhead) along with two normal diploid PMCs at prophase-1 (arrowed). (n) Two diploid PMCs showed fusion at similar phases. Scale bar $=10 \mu \mathrm{m}$.

glycero-acetocarmine $(1: 1)$ mixture. Well-filled pollen grains with stained nuclei were taken as apparently fertile while shriveled and unstained ones were counted as sterile. Chromosome spreads were analyzed with an Olympus light microscope, and the best plates of chromosome counts, meiotic abnormalities, and pollen grains were photographed from temporary mounts with a Nikon Eclipse $80 i$ microscope. Pollen size was measured through micrometry. 


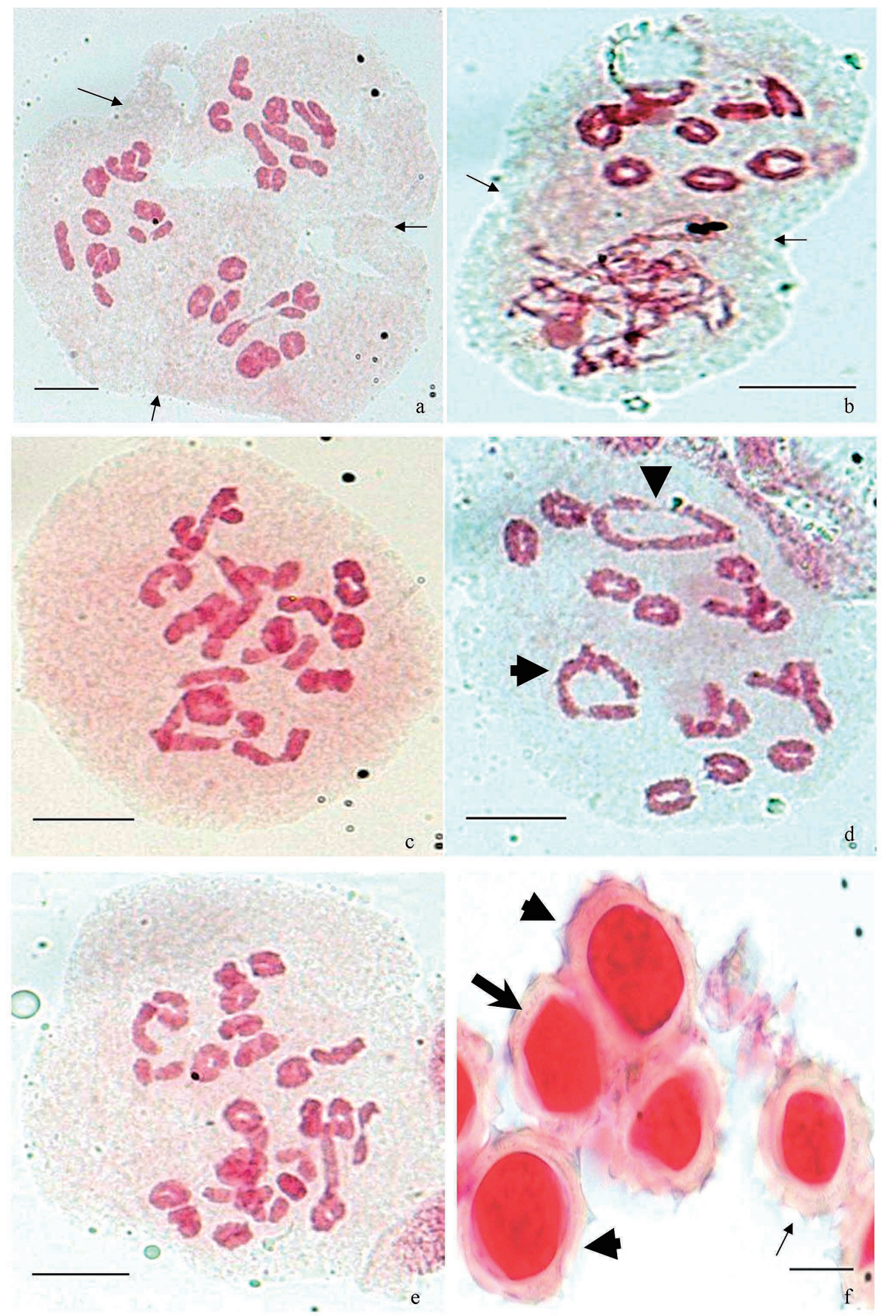

Fig. 2. (a) Three diploid PMCs undergo fusion. (b) Two diploid PMCs depict fusion at the different phases of meiosis. (c) A tetraploid PMC depicts 18 bivalents at metaphase-1. (d) A tetraploid PMC with 14 bivalents and two quadrivalents (arrowhead). (e) A hexaploid PMC with 27 bivalents at metaphase-1. (f) Heterogenous sized pollen grains as typical (arrowed), large sized pollen grains (spear-arrowhead) and very-large sized pollen grains (arrowhead). Scale bar $=10 \mu \mathrm{m}$.

Results

\section{Chromosome counts}

Present study includes a detailed male meiotic analysis and pollen grain formation in nine different accessions collected from Solang Valley and Parvati valley in Kullu district, Himachal Pradesh, India. The information on site of collection, accession number, meiotic chromosome number, meiotic course including presence of multivalents due to structural heterozygosity for re- ciprocal translocations, pollen fertility, and pollen grain size is provided in Table 1. Majority of the accessions depicted meiocytes with diploid chromosome counts of $n=9$ while two accessions showed the presence of syncytes/polyploid meiocytes with a meiotic chromosome count of $n=18$ and $n=27$.

\section{Accessions with normal meiotic course}

Of the nine accessions scored presently for male meiotic studies, the individuals of seven accessions uniformly depicted a diploid chromosome count of $n=9$ as 
revealed by the presence of nine equal-sized bivalents at M-1 (Fig. 1a). Further meiotic course including microsporogenesis was found to be regular resulting into high pollen sterility (98-100\%).

Accessions with structural heterozygosity and cell fusion

Two accessions scored from Palchan 2450 m (PUN 58571) and Dhundhi $3050 \mathrm{~m}$ (PUN 58572) which also existed at $2 x$ level depicted the presence of multiple chromosomal associations of four to eight chromosomes due to structural heterozygosity for reciprocal translocations (Figs. 1b, 1c) and fusion among two to three proximate PMCs at different stages of prophase-1 and M-1 (Figs. 1i-m).

a. Diploid PMCs with multiple chromosomal associations

Analysis of 180 normal diploid meiocytes in the two accessions revealed that $31.15 \%$ (Palchan accession) to $52.94 \%$ of the meiocytes (Dhundhi accession) showed the presence of multiple associations of four to eight chromosomes (Fig. 1b, Table 4). The multivalents in such diploid meiocytes are either ring, zigzag or typical or chain type. In Dhundhi accession, 1.68\% of the PMCs were also noticed with two univalent chromosomes (Fig. 1c). In spite of the presence of laggards at A-1/T-I and AII/T-II (Fig. 1d), majority of the PMCs showed 9:9 (Fig. 1e) and 9:9:9:9 (Fig. 1f) equal chromosomal segregation resulted into PMCs with equal sized nuclei at T-II (Fig. 1g), normal sporads and fertile equal sized pollen grains (Fig. 1h).

\section{b. Syncyte $(4 x, 6 x)$ PMCs}

These accessions (Palchan and Dhundhi) showed the fused PMCs consisting of chromatin material either at the same stage of meiotic division (Figs. 1n, 2a) or in dissimilar phases (Fig. 2b). Such syncyte PMCs depicted tetraploid (Figs. 2c, 2d) and hexaploid (Fig. $2 \mathrm{e})$ chromosome counts of $2 n=36\left(18_{\mathrm{II}}\right.$ or $\left.2 \mathrm{IV}^{+14_{\text {II }}}\right)$ and $2 n=54\left(27_{\text {II }}\right)$, respectively. Although the frequency of syncytes/polyploid PMCs was very low, at 43 out of 1889 (2.28\%) (Table 3), these could be differentiated by their larger size in a pool of typical sized ' $2 n$ ' PMCs. The tetraploid ' $4 n$ ' PMCs measure $46.52 \times 31.91-$ $48.62 \times 45.33 \mu \mathrm{m}$ while ' $6 n$ ' hexaploid PMCs were $53.68 \times 51.29-54.87 \times 52.19 \mu \mathrm{m}$ compared to the normal diploid ' $2 n$ ' PMCs $(28.63 \times 23.26-31.33 \times 19.68 \mu \mathrm{m})$. The $4 x$ and $6 x$ PMCs depicted regular constitution of 18 and 27 bivalents during diakinesis and M-1 leading to normal sporads. In spite of the fact that majority of the polyploid PMCs showed regular bivalents formation, 31.15 (Palchan)-52.94\% PMCs (Dhundhi) revealed the existence of structural heterozygosity for reciprocal translocations as is evident from the presence of multiple chromosome associations (Fig. 2d).

\section{Formation of heterogenous sized pollen grains}

Although the meiocytes (diploid and polyploid) followed a regular meiotic course with equal distribution of chromosomes, the two accessions depicted the existence of heterogenous-sized pollen grains. On size basis, the fertile pollen grains were categorized into three types, as normal sized or typical $(20.32 \times 22.39-23.09 \times 21.63 \mu \mathrm{m}, 88.48-92.21 \%)$, large-

Table 2. Analysis of chromosomal associations at diakinesis/M-I and chiasma frequency in the diploid meiocytes of Achillea millefolium.

\begin{tabular}{|c|c|c|c|c|c|c|c|c|c|c|}
\hline \multirow{3}{*}{ Accessions studied } & \multicolumn{8}{|c|}{ Chromosomal associations } & \multirow{3}{*}{$\begin{array}{c}\text { Chiasma per } \\
\text { PMC } \\
\text { (mean } \pm \text { standard } \\
\text { deviation) }\end{array}$} & \multirow{3}{*}{$\begin{array}{l}\text { Chiasma } \\
\text { per } \\
\text { bivalent }\end{array}$} \\
\hline & & Biva & ents & & uadrivalent & & \multirow{2}{*}{ Octavalent } & \multirow{2}{*}{ Univalents } & & \\
\hline & & Ring & Rod & $\begin{array}{l}\text { Zigzag } \\
\text { ring }\end{array}$ & $\begin{array}{l}\text { Typical } \\
\text { ring }\end{array}$ & Chain & & & & \\
\hline \multicolumn{11}{|l|}{ Palchan, $2450 \mathrm{~m}$} \\
\hline PMCs with nine bivalents & 42 & $\begin{array}{l}219 / 378 \\
(57.93 \%)\end{array}$ & $\begin{array}{l}159 / 378 \\
(42.06 \%)\end{array}$ & & & & & & $\begin{array}{c}11-17 \\
(13.71 \pm 1.72)\end{array}$ & 1.52 \\
\hline $\begin{array}{l}\text { PMCs with bivalents and } \\
\text { multivalents }\end{array}$ & 19 & $\begin{array}{c}59 / 107 \\
(55.14 \%)\end{array}$ & $\begin{array}{c}48 / 107 \\
(44.86 \%)\end{array}$ & $\begin{array}{l}6 / 30 \\
(20 \%)\end{array}$ & $\begin{array}{l}15 / 30 \\
(50 \%)\end{array}$ & $\begin{array}{c}9 / 30 \\
(30 \%)\end{array}$ & $\begin{array}{c}1 / 1 \\
(100 \%)\end{array}$ & & $\begin{array}{c}13-17 \\
(15.33 \pm 1.28)\end{array}$ & 1.70 \\
\hline $\begin{array}{l}\text { Total PMCs analysed \% of } \\
\text { chromosomes involved in } \\
\text { chromosomal associations }\end{array}$ & 61 & $\begin{array}{l}556 / 1098 \\
(50.64 \%)\end{array}$ & $\begin{array}{l}414 / 1098 \\
(37.70 \%)\end{array}$ & $\begin{array}{l}24 / 1098 \\
(2.19 \%)\end{array}$ & $\begin{array}{l}60 / 1098 \\
(5.46 \%)\end{array}$ & $\begin{array}{l}36 / 1098 \\
(3.28 \%)\end{array}$ & $\begin{array}{l}8 / 1098 \\
(0.73 \%)\end{array}$ & & & \\
\hline \multicolumn{11}{|l|}{ Dhundhi, $3050 \mathrm{~m}$} \\
\hline PMCs with nine bivalents & 54 & $\begin{array}{c}216 / 486 \\
(44.44 \%)\end{array}$ & $\begin{array}{l}270 / 486 \\
(55.56 \%)\end{array}$ & - & - & - & - & - & $\begin{array}{c}11-16 \\
(13.5 \pm 1.50)\end{array}$ & 1.45 \\
\hline $\begin{array}{l}\text { PMCs with eight bivalents } \\
\text { and two univalents }\end{array}$ & 2 & $\begin{array}{c}5 / 16 \\
(31.25 \%)\end{array}$ & $\begin{array}{c}11 / 16 \\
(68.75 \%)\end{array}$ & - & - & - & - & 4 & $\begin{array}{c}12-13 \\
(12.5 \pm 0.75)\end{array}$ & 1.38 \\
\hline $\begin{array}{l}\text { PMCs with bivalents and } \\
\text { multivalents }\end{array}$ & 63 & $\begin{array}{l}270 / 567 \\
(47.62 \%)\end{array}$ & $\begin{array}{l}153 / 567 \\
(26.98 \%)\end{array}$ & $\begin{array}{c}6 / 567 \\
(1.06 \%)\end{array}$ & $\begin{array}{c}63 / 567 \\
(11.11 \%)\end{array}$ & $\begin{array}{c}3 / 567 \\
(0.53 \%)\end{array}$ & - & - & $\begin{array}{c}11-19 \\
(15.76 \pm 2.08)\end{array}$ & 1.75 \\
\hline $\begin{array}{l}\text { Total PMCs analysed \% of } \\
\text { chromosomes involved in } \\
\text { associations }\end{array}$ & 119 & $\begin{array}{l}992 / 2142 \\
(46.31 \%)\end{array}$ & $\begin{array}{l}854 / 2142 \\
(39.86 \%)\end{array}$ & $\begin{array}{l}24 / 2142 \\
(1.12 \%)\end{array}$ & $\begin{array}{l}252 / 2142 \\
(11.76 \%)\end{array}$ & $\begin{array}{l}12 / 2142 \\
(0.56 \%)\end{array}$ & & $\begin{array}{l}8 / 2142 \\
(0.37 \%)\end{array}$ & & \\
\hline
\end{tabular}


sized $(25.49 \times 23.37-25.70 \times 24.77 \mu \mathrm{m}, 4.04-11.11 \%)$ and very-large sized $(28.65 \times 29.32-31.19 \times 27.31 \mu \mathrm{m}, 1.73 \%)$ (Fig. 2f, Tables 1, 4). Such large and very-large sized pollen grains might be the products of ' $4 x$ ' and ' $6 x$ ' PMCs and have ' $2 n$ ' and ' $3 n$ ' genetic constitution compared to normal-sized which have ' $n$ ' chromosome number.
Chiasma frequency

Analysis of chiasma frequency in the diploid and syncyte meiocytes on the basis of data collected on the accessions from Palchan and Dhundhi (Table 2) reveals that the mean chiasma frequency per PMC in the normal diploid PMCs with nine bivalents works out to be $13.71 \pm 1.72$ and $13.50 \pm 1.50$ with an average chiasma

Table 3. Cytological status of PMCs at different stages of meiosis in two accessions of Achillea millefolium..

\begin{tabular}{|c|c|c|c|c|c|c|c|c|c|c|}
\hline \multirow{2}{*}{$\begin{array}{l}\text { Province, } \\
\text { locality, } \\
\text { altitudes }\end{array}$} & \multirow{2}{*}{$\begin{array}{l}\text { Acces- } \\
\text { sion } \\
\text { number } \\
\text { (PUN) }\end{array}$} & \multirow{2}{*}{$\begin{array}{l}\text { Chromo- } \\
\text { some } \\
\text { number } \\
(n)\end{array}$} & \multirow[b]{2}{*}{$\begin{array}{l}\text { Meiotic } \\
\text { course }\end{array}$} & \multicolumn{2}{|c|}{ No. of PMCs analysed at M-1 } & \multirow{2}{*}{$\begin{array}{c}\% \text { of } \\
\text { PMCs } \\
\text { with lag- } \\
\text { gards at } \\
\text { A-1 }\end{array}$} & \multirow{2}{*}{$\begin{array}{c}\% \text { of } \\
\text { PMCs } \\
\text { with lag- } \\
\text { gards at } \\
\text { A-II }\end{array}$} & \multirow{2}{*}{$\begin{array}{c}\% \text { of } \\
\text { PMCs } \\
\text { with lag- } \\
\text { gards at } \\
\text { T-II }\end{array}$} & \multirow{2}{*}{$\begin{array}{l}\text { Pollen } \\
\text { fertility } \\
(\%)\end{array}$} & \multirow[b]{2}{*}{ Pollen grains size $(\mu \mathrm{m})$} \\
\hline & & & & $\begin{array}{c}\text { (without } \\
\text { multivalents) }\end{array}$ & $\begin{array}{l}\text { (with } \\
\text { multivalents) }\end{array}$ & & & & & \\
\hline \multicolumn{11}{|l|}{$\begin{array}{l}\text { Kullu district } \\
\text { Solang Valley }\end{array}$} \\
\hline Palchan, $2450 \mathrm{~m}$ & 58571 & 9 & ST & 42 & 19 & 5.45 & 6.66 & - & 68.00 & $\begin{array}{l}\text { Typical sized: } \\
23.09 \times 21.63 \mu \mathrm{m} \\
\text { Large sized: } \\
25.70 \times 24.77 \mu \mathrm{m} \\
\text { Very large sized: } \\
31.19 \times 27.31 \mu \mathrm{m}\end{array}$ \\
\hline $\begin{array}{l}\text { Solang Nullah, } \\
2700 \mathrm{~m}\end{array}$ & 56570 & 9 & Normal & 78 & - & - & - & - & 99.00 & $\begin{array}{l}\text { Typical sized: } \\
21.55 \times 22.02 \mu \mathrm{m}\end{array}$ \\
\hline $\begin{array}{l}\text { Solang Village, } \\
2750 \mathrm{~m}\end{array}$ & 56885 & 9 & Normal & 69 & - & - & - & - & 98.00 & $\begin{array}{l}\text { Typical sized: } \\
22.67 \times 21.15 \mu \mathrm{m}\end{array}$ \\
\hline Dhundhi, $3050 \mathrm{~m}$ & 58572 & 9 & ST & 54 & 63 & 8.69 & - & 4.34 & 71.49 & $\begin{array}{l}\text { Typical sized: } \\
20.32 \times 22.39 \mu \mathrm{m} \\
\text { Large sized: } \\
25.49 \times 23.37 \mu \mathrm{m} \\
\text { Very large sized: } \\
28.65 \times 29.32 \mu \mathrm{m}\end{array}$ \\
\hline \multicolumn{11}{|l|}{ Parvati Valley } \\
\hline Shaarni, $2300 \mathrm{~m}$ & 56092 & 9 & Normal & 93 & & - & - & - & 100 & $\begin{array}{l}\text { Typical sized: } \\
22.61 \times 18.98 \mu \mathrm{m}\end{array}$ \\
\hline Pulga, $2300 \mathrm{~m}$ & 56119 & 9 & Normal & 78 & & - & - & - & 100 & $\begin{array}{l}\text { Typical sized: } \\
22.41 \times 20.49 \mu \mathrm{m}\end{array}$ \\
\hline Braagha, $2600 \mathrm{~m}$ & 56111 & 9 & Normal & 62 & & - & - & - & 100 & $\begin{array}{l}\text { Typical sized: } \\
21.63 \times 21.10 \mu \mathrm{m}\end{array}$ \\
\hline Nareng, $2700 \mathrm{~m}$ & 56119 & 9 & Normal & 47 & & - & - & - & 100 & $\begin{array}{l}\text { Typical sized: } \\
22.11 \times 21.00 \mu \mathrm{m}\end{array}$ \\
\hline Mallana, $2650 \mathrm{~m}$ & 57165 & 9 & Normal & 102 & & - & - & - & 100 & $\begin{array}{l}\text { Typical sized: } \\
20.43 \times 18.88 \mu \mathrm{m}\end{array}$ \\
\hline
\end{tabular}

Table 4. Province, locality, altitudes, accession number, $\%$ of syncytes, pollen size and their relative frequency in structurally heterozygous populations of Achillea millefolium.

\begin{tabular}{lcc}
\hline \multicolumn{1}{c}{ Solang Valley } & \\
\hline Locality, altitudes & Palchan, $2450 \mathrm{~m}$ & Dhundhi, $3050 \mathrm{~m}$ \\
Accession number (PUN*) & 58571 & 58572 \\
Meiotic irregularities & $1.73 \%(22 / 1269)$ & $1.45 \%(9 / 620)$ \\
Syncytes (4x, 6x) PMCs & $31.15 \%(19 / 61)$ & $52.94 \%(63 / 119)$ \\
Diploid PMCs with multivalents & $25.00 \%(4 / 16)$ & $30.00 \%(3 / 10)$ \\
Syncytes with quadrivalents & - & $1.68 \%(2 / 119)$ \\
Diploid PMCs with univalents & $11.45 \%(11 / 96)$ & $15.17 \%(22 / 145)$ \\
PMCs with sticky chromatin & $31.45 \%(78 / 248)$ & $28.50 \%(61 / 214)$ \\
Apparent pollen sterility & & $20.32 \times 22.39\{88.88 \%\}$ \\
Average pollen size (R.F.) & $23.09 \times 21.63\{94.21 \%\}$ & $25.49 \times 23.37\{11.11 \%\}$ \\
$n$ & $25.70 \times 24.77\{4.04 \%\}$ & $-/-$ \\
$2 n$ & $31.19 \times 27.31\{1.73 \%\}$ & - \\
$3 n$
\end{tabular}

R.F.: relative frequency. Data given in the parentheses represent observed number of cytologically irregular PMCs or sterile pollen grains in the numerator and total number of PMCs or pollen grains in the denominator. *PUN is the abbreviation for herbarium of Department of Botany, Punjabi University, Patiala. 
per bivalent of 1.52 and 1.45 , respectively. On the other hand, the mean chiasma frequency per PMC and per bivalent was recorded to be significantly higher in the diploid PMCs showing structural heterozygosity for reciprocal translocations in both the accessions (15.33 $\pm 1.28,1.70$ and $15.76 \pm 2.08,1.75$, respectively). Meiocytes with bivalents and univalents showed a relatively low chiasma frequency and chiasma per bivalent of $12.5 \pm 0.75$ and 1.38 , respectively. Same trend in chiasma frequency/PMC and per bivalent has been noticed in the syncyte $4 x$ and $6 x$ PMCs (Table 5).

\section{Discussion}

Present count of diploid chromosome number $(2 n=18)$ in the studied accessions supports the earlier chromosome reports by Shetty (1964), Mehra et al. (1965), Mehra and Remanandan (1974), Mathew and Mathew (1988), and Gupta and Gill (1989), Kaur and Singhal (2015), and Rana et al. (2015) from different parts of India and by a number of workers from outside of India. Achillea millefolium which constitutes a species complex having $2 x, 3 x 4 x, 5 x, 6 x$ and $8 x$ cytotypes (based on $x=9$ ) is one of the most extensively studied species from N-W Himalayas. Recently, Singhal et al. (2014) have reported the existence of reciprocal translocations in the $2 x$ plants collected from the districts of Kullu and Kinnaur in Himachal Pradesh. On the basis of intensive and extensive study carried out presently on individual plant basis from Solang Valley and Parvati Valley, we here report the existence of reciprocal translocations in the diploid individuals. Besides, such individuals also showed the presence of cell fusion among two to three adjacent meiocytes to generate ' $4 x$ ' and ' $6 x$ ' meiocytes.

Multiple associations of chromosomes in the diploid plants depicted the occurrence of structural heterozygosity for reciprocal translocations. Reciprocal translocations, also known as chromosomal interchanges, arise due to the exchange of broken segments of nonhomologous chromosomes (Mahama and Palmer 2003, Talukdar 2013). Ever since the first report of reciprocal translocations by Belling (1914), their occurrence and possible consequences have been reported in a number of flowering plants from N-W Himalayas by various workers (Gohil and Koul 1978, Sharma and Gohil 2003, 2008, 2011, Gupta et al. 2010, Kohli and Gohil 2011, Rana et al. 2012, Kumar and Singhal 2013, Kumar et al. 2015). Presently such reciprocal translocations have been noticed in both the $2 x$ and syncyte (4x) PMCs.

Analysis of $2 x$, and $4 x$ PMCs in such $2 x$ individuals with reciprocal translocations also throw light on the level of genetic recombination in the species. On an average, the values of chiasma frequency in the meiocytes with multivalents are recorded to be higher compared to the meiocytes without multiple chromosomal associations, indicating the positive effect of reciprocal translocations on chiasma frequency. Similar increase in chiasma frequency due to multivalent formations has been observed in the $2 x$ and (4x) syncyte PMCs. However, the PMCs depicted with univalent chromosomes tend to have decreased value of chiasma frequency. Such an increase in chiasma frequency due to structural hetero-

Table 5. Analysis of chromosomal associations and chiasma frequency in syncyte PMCs at diakinesis/M-I in Achillea millefolium.

\begin{tabular}{|c|c|c|c|c|c|c|c|c|c|c|}
\hline & \multicolumn{8}{|c|}{ Chromosomal associations } & \multirow{4}{*}{$\begin{array}{c}\text { Chiasma } \\
\text { per PMC } \\
\text { (mean } \pm \text { standard } \\
\text { deviation) }\end{array}$} & \multirow{4}{*}{$\begin{array}{c}\text { Chiasma } \\
\text { per } \\
\text { bivalent }\end{array}$} \\
\hline & \multirow{3}{*}{$\begin{array}{l}\text { No. of } \\
\text { PMCs } \\
\text { analysed }\end{array}$} & Biva & lents & & Quadrivalen & & & \multirow{3}{*}{ Univalents } & & \\
\hline & & \multirow{2}{*}{ Ring } & \multirow{2}{*}{ Rod } & \multicolumn{2}{|c|}{ Ring } & \multirow{2}{*}{ Chain } & \multirow[t]{2}{*}{ Octavalents } & & & \\
\hline & & & & $\begin{array}{l}\text { Zigzag } \\
\text { ring }\end{array}$ & $\begin{array}{l}\text { Typical } \\
\text { ring }\end{array}$ & & & & & \\
\hline \multicolumn{11}{|l|}{ Palchan $(2450 \mathrm{~m})$ accession } \\
\hline $\begin{array}{l}\text { Syncyte }(4 x) \text { PMCs with } \\
18 \text { bivalents }\end{array}$ & 10 & $\begin{array}{l}101 / 180 \\
(56.11 \%)\end{array}$ & $\begin{array}{c}79 / 180 \\
(43.89 \%)\end{array}$ & - & - & - & - & & $\begin{array}{c}23-33 \\
(28.3 \pm 1.9)\end{array}$ & 1.55 \\
\hline $\begin{array}{l}\text { Syncyte }(6 x) \text { PMCs with } \\
27 \text { bivalents }\end{array}$ & 2 & $\begin{array}{c}30 / 54 \\
(55.56 \%)\end{array}$ & $\begin{array}{c}24 / 54 \\
(44.44 \%)\end{array}$ & - & - & - & - & - & $\begin{array}{c}40-44 \\
(42 \pm 2.82)\end{array}$ & 1.55 \\
\hline $\begin{array}{l}\text { Syncyte }(4 x) \text { PMCs with } \\
\text { bivalents, multivalent } \\
\text { and univalents }\end{array}$ & 4 & $\begin{array}{c}40 / 59 \\
(67.80 \%)\end{array}$ & $\begin{array}{c}19 / 59 \\
(32.20 \%)\end{array}$ & - & $\begin{array}{c}4 / 6 \\
(66.67 \%)\end{array}$ & $\begin{array}{c}2 / 6 \\
(33.33 \%)\end{array}$ & - & 2 & $\begin{array}{c}28-32 \\
(30.25 \pm 1.70)\end{array}$ & 1.68 \\
\hline $\begin{array}{l}\text { Total PMCs analysed \% of } \\
\text { chromosomes involved } \\
\text { in associations }\end{array}$ & 16 & $\begin{array}{c}342 / 612 \\
(55.88 \%)\end{array}$ & $\begin{array}{c}240 / 612 \\
(39.21 \%)\end{array}$ & & $\begin{array}{l}16 / 612 \\
(2.61 \%)\end{array}$ & $\begin{array}{c}8 / 612 \\
(1.30 \%)\end{array}$ & & $\begin{array}{c}6 / 612 \\
(0.98 \%)\end{array}$ & & \\
\hline \multicolumn{11}{|l|}{ Dhundhi (3050 m) accession } \\
\hline $\begin{array}{l}\text { Syncyte }(4 x) \text { PMCs with } \\
18 \text { bivalents }\end{array}$ & 7 & $\begin{array}{c}69 / 126 \\
(54.76 \%)\end{array}$ & $\begin{array}{c}57 / 126 \\
(45.24 \%)\end{array}$ & & & & & & $\begin{array}{c}24-30 \\
(27.71 \pm 2.49)\end{array}$ & 1.53 \\
\hline $\begin{array}{l}\text { Syncyte }(4 x) \text { PMCs with } \\
\text { bivalents, multivalent } \\
\text { and univalents }\end{array}$ & 3 & $\begin{array}{c}31 / 43 \\
(72.09 \%)\end{array}$ & $\begin{array}{c}12 / 43 \\
(27.91 \%)\end{array}$ & - & $\begin{array}{c}4 / 5 \\
(80 \%)\end{array}$ & $\begin{array}{c}1 / 5 \\
(20 \%)\end{array}$ & & & $\begin{array}{c}30-32 \\
(31 \pm 1.00)\end{array}$ & 1.72 \\
\hline $\begin{array}{l}\text { Total PMCs analysed \% of } \\
\text { chromosomes involved } \\
\text { in associations }\end{array}$ & 10 & $\begin{array}{l}200 / 360 \\
(55.55 \%)\end{array}$ & $\begin{array}{c}69 / 360 \\
(19.17 \%)\end{array}$ & - & $\begin{array}{c}16 / 360 \\
(4.44 \%)\end{array}$ & $\begin{array}{c}4 / 360 \\
(1.11 \%)\end{array}$ & & $\begin{array}{l}2 / 360 \\
(0.55 \%)\end{array}$ & & \\
\hline
\end{tabular}


zygosity has also been reported in Saxifraga diversifolia by Kumar and Singhal (2013), Achillea millefoilium (Singhal et al. 2014), and Anemone rivularis (Kumar et al. 2015).

Spontaneous occurrence of syncytes due to the fusion of adjacent meiocytes had been reported for the first time by Gates and Rees (1921) in Lactuca sativa. Since then, the phenomenon has been reported in a number of flowering plants by Levan (1941), Price (1956), Katayama (1964), Mehra and Kalia (1973), Rao and Koduru (1978), Sarbhoy (1980), Padmaja (1988), CaetanoPereira et al (1999), Mendes-Bonato et al. (2001, 2003), Boldrini et al. (2006); Risso-Pascotto et al. (2006), Singhal and Kumar (2008, 2010); Kim et al. (2009), Singhal et al. (2010, 2011); Kumar et al. (2010, 2011, 2012); Kumar and Singhal 2012, and Malik et al. (2014). In the present study, we report for the first time the formation of syncytes through fusion of two to three adjacent PMCs in the diploid populations of Achillea millefolium. The resultant polyploid PMCs with double or triple the genetic material could be recognized by their much larger size and have tetraploid and hexaploid chromosome numbers. Furthermore, such PMCs follow perfectly regular meiotic course with 18 and 27 bivalents respectively, equal chromosome segregation during A-1 and normal sporads formation. However, both the diploid accessions possessing normal $(2 n)$ PMCs and syncyte meiocytes $(4 n, 6 n)$, yielded heterogenous sized viable pollen grains, as typical, large and very large-sized. The typical pollen grains which are the products of normal ' $2 n$ ' PMCs possess ' $n$ ' genetic constitution. Although the syncytes occur at higher frequency (16.77-29.16\%), the fusion among proximate PMCs occurred at early stages of meiosis I and the products of such PMCs yielded large and very large-sized atypical pollen grains occurring at rather low frequencies of $4.04-11.11 \%$ and $1.73 \%$ with ' $2 n$ ' and ' $3 n$ ' genetic constitution, respectively.

The exact cytological status of such large and verylarge sized viable pollen grains could not be ascertained during the present study but their higher cytological status (' $2 n$ ' and ' $3 n$ ') is clearly depicted from their almost double and treble size compared to typical ' $n$ ' pollen grains as increasing DNA content may in turn influence the pollen diameter (Vorsa and Bingham 1979, Pundir et al. 1983, Bamberg and Hanneman 1991, Jansen and Den Nijs 1993, Bretagnolle and Thompson 1995, Ortiz 1997). The origin of such polyploid PMCs due to cell fusion or whole chromatin transfer during cytomixis and the production of large-sized pollen grains with unreduced $(2 n)$ genetic constitution has also been reported in Chrysanthemum (Kim et al. 2009), Lindelofia longiflora (Singhal et al. 2011), inter-specific hybrids of Brassica (Mason et al. 2011), and Mertensia echioides (Malik et al. 2014). Origin of gametes with unreduced genetic constitution in the diploid plants also referred as diplogametes (De Storme and Geelen 2013) as a product of cell fusion might have played an important role in the origin of intraspecific polyploid cytotypes $(3 x, 4 x, 5 x, 6 x, 7 x$, $8 x$ ) in the presently studied species. Kim et al. (2009) in Chrysanthemum, Singhal et al. (2011) in Lindelofia longiflora, Malik et al. (2014) in Mertensia echioides have also advocated the role of cell fusion mediated syncyte formation and subsequently the participation of ' $2 n$ ' and ' $3 n$ ' pollen grains in fertilization to generate polyploid offspring and thereby constitute the basis for the establishment of intraspecific polyploid cytoypes.

Syncyte formation as a result of cell fusion has been recorded in a wide variety of flowering plants, both dicots and monocots. But the possible factor/s responsible is yet to be ascertained. Divergent views have been put forward by different workers as the effect of chemicals, X-rays, temperature, moisture stress, culture conditions or genetic factors (Stern 1946, Merwine and Bennett 1966, Pantulu and Manga 1971, Rao and Koduru 1978, Rao et al. 1991, Nirmala and Rao 1996, Kumar and Srivastava 2009, Mason et al. 2011, Pecrix et al. 2011, De Storme et al. 2012, Singhal et al. 2011, Malik et al. 2014). In the presently studied diploid populations of Achillea millefolium, the origin of syncytes due to the fusion of two to three PMCs and structural heterozygosity for reciprocal translocations could be attributed to low temperature stress conditions coupled with ecologically disturbed habitats due to various anthropogenic activities like grazing, construction of roads, and tunnels in conjunction with natural calamities of cloud bursts and landslides prevailing in Solang valley where temperature dips to below freezing point during May-June when the plants enter the flowering stage as suggested by Singhal et al. (2011) in Lindelofia longiflora.

\section{References}

Androshchuk, A. F., Klokov, M. V., Kritskaya, L. I. and Kostinenko, L. D. 1979. Tysyachelistnik obyknovennyj Achillea millefolium L. (Asteraceae) na Ukraine (Achillea millefolium L. (Asteraceae) in the Ukraine). Bot. Zhurn. 64: 378-386.

Bala, S. and Gupta, R. C. 2011. In: Marhold, K. (ed.). IAPT/IOPB chromosome data 12. Taxon 60: 1784-1796.

Bamberg, J. B. and Hanneman, R. E. 1991. Rapid ploidy screening of tuber-bearing Solanum (potato) species through pollen diameter measurement. Am. Potato J. 68: 279-285.

Belling, J. 1914. The mode of inheritance of semisterility in the offspring of certain hybrid plants. Z. Indukt. Abstamm. Vererbungsl. 12: 303-342.

Boldrini, K. R., Pagliarini, M. S. and Valle, C. B. 2006. Cell fusion and cytomixis during microsporogenesis in Brachiaria humidicola (Poaceae). S. Afr. J. Bot. 72: 478-481.

Bretagnolle, F. and Thompson, J. D. 1995. Gametes with the somatic chromosome number: Mechanisms of their formation and role in the evolution of autopolyploid plants. New Phytol. 129: 1-22.

Caetano-Pereira, C. M., Pagliarini, M. S. and Brasil, E. M. 1999. Cell fusion and chromatin degeneration in an inbreed line of maize. Genet. Mol. Biol. 22: 69-72.

Clausen, J., Keck, D. D. and Hiesey, W. M. 1941. Experimental studies on the nature of species. I. Effect of varied environments on 
western North American plants. Madrono 6: 60-63.

Danihelka, J. and Rotreklová, O. 2001. Chromosome numbers within the Achillea millefolium and the A. distans groups in the Czech Republic and Slovakia. Folia Geobot. 36: 163-191.

De Storme, N. and Geelen, D. 2013. Sexual polyploidization in plantscytological mechanisms and molecular regulation. New Phytol. 198: $670-684$.

De Storme, N., Copenhaver, G. P. and Geelen, D. 2012. Production of diploid male gametes in Arabidopsis by cold-induced destabilization of postmeiotic radial microtubule arrays. Plant Physiol. 160: 1808-1826.

Ehrendorfer, F. 1953. Systematische und zytogenetische Untersuchungen an europäischen Rassen des Achillea millefolium-Komplexes. Österr. Bot. Z. 100: 583-592.

Ehrendorfer, F. 1957. Akzessorische Chromosomen, Kreuzungssterilität und Polyploidie beim Achillea millefolium-Komplex (Compositae). Naturwissenschaften 44: 405-406.

Ehrendorfer, F. 1959. Achillea roseo-alba Ehrendf., spec. nov., eine hybridogene Sippe des Achillea millefolium-Komplexes. Österr. Bot. Z. 106: 363-368.

Ehrendorfer, F. 1960a. Akzessorische Chromosomen bei Achillea: Auswirkungen auf das Fortpflanzungssystem, Zahlen-Balance und Bedeutung für die Mikro-Evolution. Zur Phylogenie der Gattung Achillea, VI. Z. Vererb. 91: 400-422.

Ehrendorfer, F. 1960b. Akzessorische Chromosomen bei Achillea: Struktur, zytologisches Verhalten, zahlenmäßige Instabilität und Entstehung. Zur Phylogenie der Gattung Achillea, V. Chromosoma 11: 523-552.

Felföldy, L. J. M. 1947. Chromosome numbers of certain Hungarian plants. Arch. Biol. Hungarica 17: 101-103.

Gates, R. R. and Rees, E. M. 1921. A cytological study of pollen development in Lactuca. Ann. Bot. 35: 365-398.

Gervais, C. 1977. Cytological investigation of the Achillea millefolium complex (Compositae) in Quebec. Can. J. Bot. 55: 796-808.

Gohil, R. N. and Koul, A. K. 1978. Structural hybridity in Allium consanguineum. Cytologia 43: 243-247.

Gupta, R. C. and Gill, B. S. 1989. Cytopalynology of north and central Indian Compositae. J. Cytol. Genet. 24: 96-105.

Gupta, R. C., Himshikha, Rana, P. K., Kumar, P. and Singhal, V. K. 2010. First report of structural heterozygosity in Artemisia parviflora (Asteraceae) from Parvati Valley in Kullu District (Himachal Pradesh, India). Bot. Serb. 34: 63-66.

Harling, G. 1950. Embryological studies in the Compositae, I, Anthemideae-Anthemidinae. Acta Horti. Bergiani 15: 135-168.

Jansen, R. C. and Den Nijs, A. P. M. 1993. The statistical analysis of ' $2 n$ ' and ' $4 n$ ' pollen formation in Lolium perenne using pollen diameters. In: Proceedings of the 16th Meeting of the Fodder Crop Section of Eucarpia, Wageningen, The Netherlands.

Katayama, T. 1964. Studies on the syncyte formation induced by Xrays in rice plants. Jpn. J. Genet. 39: 217-221.

Kaur, M. and Singhal, V. K. 2015. Cytomorphological diversity in some members of family Asteraceae from the ecologically disturbed habitats of Solang valley, Kullu district, Himachal Pradesh. Cytologia 80: 203-222.

Kim, J. S., Oginuma, K. and Tobe, H. 2009. Syncyte formation in the microsporangium of Chrysanthemum (Asteraceae): A pathway to infraspecific polyploidy. J. Plant Res. 122: 439-444.

Kohli, B. and Gohil, R. N. 2011. Is Allium roylei Stearn still evolving through multiple interchanges? Nucleus 54: 19-23.

Kumar, G. and Srivastava, P. 2009. Gibberellic acid induced pollen mortality and abnormal microsporogenesis in safflower. Cytologia 74: 171-176.

Kumar, P. and Singhal, V. K. (2012). Meiotic aberrations and chromosomal variations in the plants of Lahaul-Spiti and adjoining high hills in Himachal Pradesh. In: Atri, N. S., Gupta, R. C., Saggoo, M. I. S. and Singhal, V. K. (eds.). Biodiversity Evaluation: Botan- ical Perspective. Bishen, Singh Mahendra Pal Singh DehraDun. pp. 147-170.

Kumar, P. and Singhal, V. K. 2013. Reduction in chiasma frequency and pollen fertility due to multiple chromosomal associations and univalents in Saxifraga diversifolia from alpine regions of northwest Himalayas (India). Caryologia 66: 120-127.

Kumar, P., Singhal, V. K. and Kaur, D. 2012. Impaired male meiosis due to irregular synapsis coupled with cytomixis in a new diploid cytotype of Dianthus angulatus (Caryophyllaceae) from Indian cold deserts. Folia Geobot. 47: 59-68.

Kumar, P., Singhal, V. K., Kaur, D. and Kaur, S. 2010. Cytomixis and associated meiotic abnormalities affecting pollen fertility in Clematis orientalis. Biol. Plant. 54: 181-184.

Kumar, P., Singhal, V. K., Rana, P. K., Kaur, S. and Kaur, D. 2011. Cytology of Ranunculus laetus Wall. ex Royle from cold desert regions and adjoining hills of North-west Himalayas. Caryologia 64: $25-32$.

Kumar, R., Rana, P. K., Himshikha., Kaur, D., Kaur, M., Singhal, V. K., Gupta, R. C. and Kumar, P. 2015. Structural heterozygosity and cytomixis driven pollen sterility in Anemone rivularis Buch.-Ham. ex DC. from Western Himalaya (India). Caryologia 68: $246-253$.

Lavrenko, A. N. and Serditov, N. P. 1991. Chromosome numbers in some plant species from the south-western part of the Komi Autonomous Soviet Republic. Bot. Zhurn. 76: 769-771 (in Russian).

Levan, A. 1941. Syncyte formation in the pollen mother cells of haploid Phleum pratense. Hereditas 27: 243-252.

Löve, A. and Löve, D. 1944. Cytotaxonomical studies on boreal plants. III. Some new chromosome numbers of Scandinavian Plants. Ark. Bot. 12: 1-22.

Löve, A. and Löve, D. 1948. Chromosome Numbers of Northern Plant Species. Ingolfsprent, Kopavogi.

Mahama, A. A. and Palmer, R. G. 2003. Translocation breakpoints in soybean classical genetic linkage groups 6 and 8. Crop Sci. 43: 1602-1609.

Malik, R. A. 2012. Cytomorphological investigations on some members of Gamopetalae from Kashmir. Ph.D. Thesis, Punjabi University, Patiala.

Malik, R. A., Gupta, R. C., Kumari, S. and Malik, A. H. 2014. Cytomictic anomalous male meiosis and $2 n$ pollen grain formation in Mertensia echioides Benth. (Boraginaceae) from Kashmir Himalaya. Scientific World Journal 2014: 134192.

Mason, A. S., Nelson, M. N., Yan, G. J. and Cowling, W. A. 2011. Production of viable male unreduced gametes in Brassica interspecific hybrids is genotype specific and stimulated by cold temperatures. BMC Plant Biol. 11: 103.

Mathew, A. and Mathew, P. M. 1988. Cytological studies on the south Indian Compositae. Glimpses Pl. Res. 8: 1-177.

Mehra, P. N., Gill, B. S., Mehta, J. K. and Sidhu, S. S. 1965. Cytological investigations on the Indian Compositae. I. North-Indian taxa. Caryologia 18: 35-68.

Mehra, P. N. and Kalia, V. 1973. Accessory chromosomes and multinucleate pollen mother cells in Saccharum benghalense Retz. complex. Nucleus 16: 75-78.

Mehra, P. N. and Remanandan, P. 1974. Cytological investigations on the Indian Compositae. II. Astereae, Heliantheae, Helenieae and Anthemideae. Caryologia 27: 255-284.

Mendes-Bonato, A. B., Pagliarini, M. S., Silva, N. and Valle, C. B. 2001. Meiotic instability in invader plants of signal grass Brachiaria decumbens Stapf (Gramineae). Genet. Mol. Biol. 23: 619-625.

Mendes-Bonato, A. B., Risso-Pascotto, C., Pagliarini, M. S. and Valle, C. B. 2003. Normal microspore production after cell fusion in Brachiaria jubata (Gramineae). Genet. Mol. Biol. 26: 517-520.

Merwine, N. C. and Bennett, H. W. 1966. Syncytes in meiosis of polyploid Sorghum. Crop Sci. 6: 155-157. 
Nirmala, A. and Rao, P. N. 1996. Genesis of chromosome numerical mosaicism in higher plants. Nucleus 39: 151-175.

Ortiz, R. 1997. Occurrence and inheritance of $2 n$ pollen in Musa. Ann. Bot. 79: 449-453.

Padmaja, V. 1988. Studies on manifold abnormalities at meiosis in Petunia $(2 n=14)$. Cytologia 53: 199-204.

Pantulu, J. V. and Manga, V. 1971. Monofactorial "multiploid sporocytes" condition induced by EMS in pearlmillet. Genetica 42: 214-218.

Pecrix, Y., Rallo, G., Folzer, H., Cigna, M., Gudin, S. and Le Bris, M. 2011. Polyploidization mechanisms: Temperature environment can induce diploid gamete formation in Rosa sp. J. Exp. Bot. 62: 3587-3597.

Polya, L. 1948. Chromosome numbers of certain alkali plants. Arch. Biol. Hung. 18: 145-148.

Polya, L. 1949. Chromosome numbers of some Hungarian plants I. Acta Geobot. Hung. 6: 124-137. (in Hungarian)

Polya, L. 1950. Chromosome numbers of some Hungarian plants II. Ann. Biol. Univ. Debrecen. 1: 46-56. (in Hungarian)

Price, S. 1956. Cytological studies in Saccharum and allied genera. 1. Syncytes in certain clones of Saccharum and Erianthus. Cytologia 21: 21-37.

Pundir, R. P. S., Rao, N. K. and van der Maesen, L. J. G. 1983. Induced autotetraploidy in chickpea (Cicer arietinum L.). Theor. Appl. Genet. 65: 119-122.

Rana, P. K., Himshikha., Kumar, P., Singhal, V. K. and Gupta, R. C. 2012. Impact of reciprocal translocations and non-synchronous disjunction of chromosomes on pollen fertility in Astragalus chlorostachys from North-West Himalayas (India). Cytologia 77: 173-179.

Rana, P. K., Kumar, P. and Singhal, V. K. 2015. Chromosome counts, chromosomal pairing, and pollen fertility in thirty-eight species of Asteraceae from Pangi Valley in District Chamba of Himachal Pradesh (India). Braz. J. Bot. 38: 837-850.

Rao, M. K. and Koduru, P. R. K. 1978. Cytogenetics of a factor for syncyte formation and male sterility in Pennisetum americanum. Theor. Appl. Genet. 53: 1-7.

Rao, P. N., Nirmala, A. and Ranganadham, P. 1991. Cytogenetic studies of plasmodial sporocytes, chromatin disintegration, desynapsis and centromere breakage in pearl millet. Cytologia 56: $165-171$.

Rehberger, U. 2000. In: Dobea, C. and Vitek, E. (eds.). Documented Chromosome Number Checklist of Austrian Vascular Plants. Verlag des Naturhistorischen Museums Wien, Vienna.

Risso-Pascotto, C., Pagliarini, M. S. and Valle, C. B. 2006. Micro- sporogenesis in Brachiaria dictyoneura (Fig. \& De Not.) Stapf (Poaceae; Paniceae). Genet. Mol. Res. 5: 837-845.

Sarbhoy, R. K. 1980. Spontaneous occurrence of cytomixis and syndiploidy in Cyamopsis tetragonoloba (L.) Taub. Cytologia 45: 375-379.

Saukel, J. and Langer, R. 1992. Die Achillea millefolium-Gruppe (Asteraceae) in Mitteleuropa, 1. Phyton (Horn) 31: 185-207.

Sharma, G. and Gohil, R. N. 2003. Cytology of Allium roylei Stearn. I. Meiosis in a population with complex interchanges. Cytologia 68: 115-119.

Sharma, G. and Gohil, R. N. 2008. Intrapopulation karyotypic variability in Allium roylei Stearn-a threatened species. Bot. J. Linn. Soc. 158: 242-248.

Sharma, G. and Gohil, R. N. 2011. Occurrence of differential meiotic associations and additional chromosomes in the embryo-sac mother cells of Allium roylei Stearn. J. Genet. 90: 45-49.

Shetty, V. A. 1964. Chromosome numbers in some flowering plants. Curr. Sci. 33: 58-59.

Singhal, V. K. and Kumar, P. 2008. Impact of cytomixis on meiosis, pollen viability and pollen size in wild populations of Himalayan poppy (Meconopsis aculeata Royle). J. Biosci. 33: 371-380.

Singhal, V. K. and Kumar, P. 2010. Variable sized pollen grains due to impaired male meiosis in the cold desert plants of Northwest Himalayas (India). In: Kaiser, B. J. (ed.). Pollen: Structure, Types and Effects. Nova Science Publishers Inc., New York. pp. 101-126.

Singhal, V. K., Kaur, S. and Kumar, P. 2010. Aberrant male meiosis, pollen sterility and variable sized pollen grains in Clematis montana Buch.-Ham. ex DC. from Dalhousie hills, Himachal Pradesh. Cytologia 75: 31-36.

Singhal, V. K., Rana, P. K. and Kumar, P. 2011. Syncytes during male meiosis resulting in ' $2 n$ ' pollen grain formation in Lindelofia longiflora var. falconeri. J. Syst. Evol. 49: 406-410.

Singhal, V. K., Kaur, D., Kaur, M., Himshikha., Rana, P. K., Kumar, P. and Gupta, R. C. 2014. Multiple associations due to structural heterozygosity in the wild plants of Achillea millefolium L. from Northwest Himalayas (India). Cytologia 79: 151-159.

Stern, H. 1946. The formation of polynucleated pollen mother cells in Trillium erectum. J. Hered. 37: 47-50.

Talukdar, D. 2013. Cytogenetics of a reciprocal translocation integrating distichous pedicel and tendril-less leaf mutations in Lathyrus sativus L. Caryologia 66: 21-30.

Vorsa, N. and Bingham, E. T. 1979. Cytology of ' $2 n$ ' pollen formation in diploid alfalfa, Medicago sativa. Can. J. Genet. Cytol. 21: $525-530$. 